\title{
DAMPAK KETERAMPILAN DOSEN DALAM PENGELOLAAN KELAS TERHADAP MOTIVASI BELAJAR MAHASISWA
}

\author{
Ahmad Afandi \\ Pendidikan Bahasa Arab-Universitas Islam Negeri Maulana Malik Ibrahim Malang \\ Email: afandi.ahmad21@gmail.com
}

\begin{abstract}
Abstrak
Penelitian bertujuan mengetahui pengelolaan kelas yang dilakukan oleh dosen dalam pembelajaran bahasa Arab kelas PKPBA UIN Maulana Malik Ibrahim Malang dan dampaknya terhadap motivasi belajar mahasiswa. Metodologi yang digunakan adalah pendekatan kualitatif dengan metode deskriptif. Teknik pengumpulan data yang digunakan yaitu observasi partisipasi pasif, dan wawancara melalui pedoman observasi dan wawancara. Sumber data dalam penelitian ini menggunakan sumber data primer dan sekunder. Analisis dalam penelitian disajikan secara deskriptif kualitatif dengan menggunakan subjek penelitian dosen mata kuliah Kalam, dan Mahasiswa kelas PKPBA UIN Maulana Malik Ibrahim Malang. Kesimpulannya adalah keterampilan pengelolan kelas yang dilakukan oleh dosen mata kuliah kalam dalam menyiapkan kelas, pengendalian perilaku mahasiswa, menyajikan materi, mampu menciptakan suasana kelas yang kondusif dan menjadi faktor ekstrinsik mahasiswa terhadap motivasi belajar mereka.
\end{abstract}

Kata Kunci: keterampilan dosen, pengelolaan kelas, motivasi belajar

\section{Pendahuluan}

Manajemen kelas merupakan dasar keterampilan yang harus dimiliki guru. Bagaimana guru mampu menciptakan dan menyiapkan kondisi kelas yang kondusif bagi siswa selama kegiatan belajar-mengajar berlangsung.

Dalam pembelajaran pendidik memiliki tanggungjawab yang amat besar dalam upaya mengantarkan peserta didik kearah tujuan pendidikan yang dicita-citakan. Sebab pendidikan merupakan culture transition yang bersifat dinamis kearah suatu perubahan secara berkesinambungan. Sebagai sarana penting membangun kebudayaan dan peradaban umat manusia. Guru bertanggung jawab memenuhi kebutuhan peserta didik, baik spiritual, intelektual, moral estetika maupun fisik peserta didik (Nizar, 2002, 41).

Guru yang kurang menguasai materi keilmuan maupun metode pengajaran yang digunakan, akan berdampak pada siswa-siswa yang hanya menerima pelajaran sebatas hafalan yang akan keluar dalam ujian, tanpa berefek pada sikap dan kepribadian. Padahal pendidikan itu bermakna adanya perubahan tingkah laku anak melalui pengalaman belajarnya di kelas. Itulah mengapa proses belajar mengajar sering dikaitkan dengan perubahan perilaku. 
Belum lagi pembaruan yang terus berkembang dalam dunia pendidikan meliputi, pembaruan kurikulum, metode belajar, administrasi pendidikan, media pendidikan dan pembaruan sistem supervise menyebabkan timbulnya perubahan bahan ukuran baik-buruk perihal kegiatan guru, kegiatan siswa, suasana kelas dan sebagainya (Arikunto, 1992, 2). Pembaruan-pembaruan ini memberikan pengaruh besar terhadap persiapan dan cara mengajar seorang guru serta memengaruhi persiapan dan kondisi belajar siswa di kelas, begitu juga dengan metode mengajar yang berbeda memiliki pengaruh terhadap suasana belajar di kelas. Tindakan pengelolaan kelas adalah tindakan yang menunjuk kepada kegiatan-kegiatan menciptakan dan mempertahankan kondisi yang optimal bagi terjadinya belajar-mengajar (Rohani, 2010, 143).

Kalau melihat dari peserta didik, tingkah laku dan perbuatan mereka selalu berubah. Hari ini mereka dapat belajar dengan baik dan tenang, tetapi besok belum tentu baik karena terjadi persaingan di kelas, oleh sebab itu kelas menjadi dinamis dalam bentuk perilaku, mental, dan emosional. Dan hal ini yang melatarbelkangi pentingnya penguasaan manajemen kelas oleh guru.

Dalam penelitian Rury Sandra Dewi (2012) menyebutkan bahwa pengelolaan kelas dalam PBM di SMP se-kecamatan muntilan menghadapi beberapa masalah dalam pengelolaan kelas. Dari segi individu siswa itu sendiri meliputi: tingkah laku siswa yang ingin mendapat perhatian orang lain, ingin menunjukkan kemampuannya, ingin menyakiti orang lain, tingkah laku sebagai peragaan ketidakmampuan. Dari segi kelompok meliputi mudahnya suatu kelompok siswa beralih perhatiannya dari tugas guru, semangat kerja rendah, kelas mereaksi negatif terhadap salah seorang anggota, kelas belum mampu menyesuaikan diri dengan keadaan baru dan keadaan kelas kurang kohesif, kelas yang mendukung teman yang melanggar norma.

Dwi Pratiwi Wulandari dan Suwarno (2016) dalam "pengaruh pengelolaan kelas dan minat belajar terhadap prestasi belajar siswa mata pelajaran ipa" meneliti tentang pengaruh pengelolaan kelas terhadap prestasi belajar siswa mata pelajaran ipa kelas IV SD Muhammadiyah 23 Surakarta, pengaruh minat belajar siswa terhadap prestasi belajar, pengaruh pengelolaan kelas dan minat terhadap prestasi siswa. Dwi dan Suwarno menyimpulkan bahwa adanya pengaruh pengelolaan kelas terhadap prestasi belajar, minat terhadap prestasi belajar, pengaruh pengelolaan kelas dan minat terhadap prestasi belajar. Penelitian ini menggungakan metodologi kuantitatif. 
Andyarto Sujana (2004) dalam penelitiannya efektifitas pengelolaan kelas membahas tentang hubungan antara motivasi kerja guru dan gaya kepemimpinan guru terhadap efektifitas pengelolaan kelas di SMU Kristen BPK Penabur Jakarta. Sujana menyimpulkan adanya hubungan positif baik secara sendiri-sendiri maupun bersamaan antara variabel bebas dan terikat. Akan tetapi dalam kenyataanya perhatian terhadap motivasi guru dan gaya kepemimpinan guru masih perlu ditingkatkan agar pembelajaran bisa lebih meminimalisir gangguan di kelas saat PBM. Dan metode penelitian yang digunakan adalah deskriptif korelasional.

Penelitian ini bertujuan untuk mengetahui keterampilan pengelolaan kelas oleh dosen dalam pembelajaran, dan dampaknya terhadap motivasi belajar siswa.

\section{Pengelolaan kelas}

Pengertian dan Fungsi Pengelolaan Kelas

Pengelolaan merupakan padanan makna dari kata manajemen. Manajemen berasal dari bahasa inggris "Management" yang bermakna ketatalaksanaan, tata pimpinan, dan pengelolaan. Dalam pengertian umum manajemen berarti pengadministrasian, pengaturan atau penataan suatu kegiatan (Arikunto, 1990, 2). Sedangkan kelas merupakan sekelompok siswa pada waktu yang sama menerima pelajaran yang sama dari guru yang sama (Arikunto, 1992, 17). Kelas merupakan lingkungan belajar yang tercipta dengan kesadaran kolektif dari suatu komunitas yaitu siswa dan memilki tujuan yang sama (Fathurrohman, Pupuh \& M. Sobry Sutikno, 2011, 103).

Adapun pengelolaan kelas adalah sebagai suatu usaha/keterampilan guru dalam proses belajar mengajar agar tercapai pembelajaran yang optimal sehingga pembelajaran dapat terlaksana sesuai dengan apa yang diharapkan (Arikunto, 1992, 67). Untuk mencapai pembelajaran yang diharapkan guru berusaha menciptakan lingkungan belajar yang kondusif, memanfaatkan sarana/fasilitas yang ada, menjaga keterlibatan siswa dan sebagainya agar tercapai pembelajaran yang efektif (Arikunto, $1990,195)$.

Kemudian, keterampilan pengelolaan kelas didefinisikan sebagai kemampuan dalam menciptakan dan mempertahankan kondisi kelas yang optimal guna terjadinya proses belajar mengajar yang serasi dan efektif, Menurut Mulyasa keterampilan 
manajemen kelas adalah kemampuan guru menciptakan iklim pembelajaran yang kondusif dan mengembalikannya jika terjadi gangguan dalam proses pembelajaran (Mulyasa, 2005, 91). Setelah memaparkan pengertian pengelolaan kelas menurut para ahli dapat disimpulkan bahwa pengelolaan kelas adalah keterampilan guru dalam memimpin kelas, mengatur, agar tercipta kondisi kelas yang kondusif sehingga proses belajar-mengajar menjadi optimal dan tercapai tujuan pembelajaran.

Dalam prakteknya pengelolaan kelas memiliki fungsi manajerial meliputi:

a. Perencanaan yaitu penetapan tujuan dan kompetensi serta cara guru dalam menyampaikan pembelajarannya. Guru sebagai manajer pembelajaran harus mampu mengambil keputusan yang tepat dalam mengelola sumber daya (siswa) dan sumber belajar untuk membentuk kompetensi dasar dan mencapai tujuan pembelajaran.

b. Pelaksanaan yaitu proses yang memberikan kepastian bahwa proses belajar mengajar telah memilki sumber daya manusia dan sarana prasarana yang diperlukan, sehingga dapat membentuk kompetensi dan mencapai tujuan yang diinginkan. Pada fungsi ini guru sebagai manajer memiliki kemampuan pengorganisasian berbagai kegiatan selama proses belajar mengajar serta kemampuan mempengaruhi pihak lain seperti bagaimana guru mampu memotivasi siswa agar mereka dapat mencapai tujuan dan kompetensi pembelajaran.

c. Pengendalian yaitu guru harus melakukan evaluasi untuk menjamin kinerja yang dicapai apakah sesuai dengan rencana atau tujuan yang telah ditetapkan. Dengan cara membandingkan kinerja actual dengan kinerja standar. Guru harus mengambil tindakan ketika terdapat perbedaan yang signifikan atau adanya kesenjangan antara proses pembelajaran actual di dalam kelas dengan yang telah direncanakan (Mulyasa, 2008, 77-78).

Mengutip dari Djamarah $(2006,185)$ untuk memperkecil masalah atau gangguan dalam pengelolaan kelas dapat menerapkan prinsip pengeloaan kelas. Beberapa prinsip tersebut meliputi hangat dan atusiasme, tantangan, bervariasi, keluwesan, penekanan hal positif dan peranan kedisiplinan. 
Pendekatan Dalam Pengelolaan Kelas

Ketika guru hendak menangani suatu kasus pengelolaan kelas maka sebelumnya guru mendalami pendekatan-pendekatan agar mampu menentukan penggunaan pendekatan itu cocok dan menjadi solusi dari suatu kasus yang akan ditangani. Dapat dikatakan bahwa interaksi yang optimal bergantung pada pendekatan yang guru lakukan dalam rangka pengelolaan kelas agar pembelajaran itu efektif. Ahmad Rohani (2010, 150-160) menyebutkan 4 pendekatan dalam pengelolaan kelas sebagai berikut:

\section{a. Behavior-modification approach}

Modifikasi perilaku bertolak pada psikologi behaviorisme yang menganggap perilaku manusia yang baik maupun buruk merupakan hasil belajar. Dalam membentuk perilaku dibutuhkan stimulus, kemudian respon berupa perilaku positif akan diberikan penguatan (reinforcement) agar perilaku baru itu bertahan, untuk mengurangi atau menghilangkan perilaku yang tidak dikehendaki dilakukan penghapusan (extinction) dan hukuman (punishment) yang dilakukan secara tidak langsung.

\section{b. Socio-emotional climate approach}

Pendekatan sosio-emosional bertolak dari psikologi klinis dan konseling. Pendekatan ini mengutamakan pada hubungan yang baik antar personal di dalam kelas, baik itu guru dengan peserta didik maupun peserta didik dengan peserta didik, sehingga peserta didik merasa aman dan senang berada dalam kelas serta berpartisipasi dalam proses belajar mengajar dalam kelas. Dengan kata lain peran guru sangat penting dalam menciptakan iklim belajar yang kondusif dan guru diharapkan dapat merasakan apa yang dirasakan oleh peserta didik serta mampu menyikapinya secara demokratis.

\section{c. Group-process approach}

Pendekatan proses kelompok berangkat dari psikologi sosial dan dinamika kelompok, dengan anggapan bahwa proses belajar-mengajar yang efektif dan efisien berlangsung dalam konteks kelompok. Untuk itu guru harus mengusahakan agar kelas menjadi suatu ikatan kelompok yang kuat. Pendekatan ini berpandangan bahwa pengalaman belajar peserta didik didapat dari kegiatan kelompok di mana dalam kelompok terdapat norma-norma yang harus diikuti oleh anggotanya, terdapat tujuan 
yang ingin dicapai, adanya hubungan timbal balik antar anggota kelompok untuk mencapai tujuan, serta memelihara kelompok yang produktif.

\section{d. Elektik approach}

Pengelolaan kelas yang berusaha menggunakan berbagai macam pendekatan yang memiliki potensi untuk dapat menciptakan dan mempertahankan suatu kondisi memungkinkan proses belajar mengajar berjalan efektif dan efisien.

Strategi pengelolaan kelas

Dalam rangka menciptakan suasana belajar yang efektif dan optimal terdapat strategi dalam melakukan pengelolaan kelas yang bersifat teknis. Strategi pengelolaan kelas meliputi:

a. Penataan Lingkungan Belajar

Kelas sebagai lingkungan belajar yang di dalamnya terjadi proses pembelajaran dan perolehan pengalaman belajar dapat dibagi menjadi lingkungan fisik dan sosial. Lingkungan fisik meliputi penataan bangku dalam kelas, hiasan dinding, papan tulis, kebersihan kelas. Adapun lingkungan sosial meliputi interaksi guru dengan siswa, siswa dengan siswa, serta guru dan siswa terhadap lingkungan sekitarnya (Rianto, 2007, 1).

Dalam penataan lingkungan belajar iklim kelas yang kondusif adalah pertimbangan utama karena mampu memberikan daya tarik tersendiri terhadap proses pembelajaran. Fasilitas belajar sebagai sarana juga berperan dalam menciptakan iklim belajar yang kondusif seperti laboratorium untuk pratikum, atau sarana lainnya (Majid, 2006).

b. Cara pengajaran guru

Pada bagian ini guru harus mampu menguasai materi pelajaran, strategi pengajaran, beberapa keahlian seperti manajemen kelas, motivasional, komunikasi dan mampu mengaplikasikan ragam kemampuannya secara fleksibel (Santrock, 2008, 7-8). Guru dapat memilih metode-metode pembelajaran yang beragam, seperti metode ceramah, diskusi, debat, demonstrasi, pengarahan untuk seluruh kelas. Ketika pembelajaran akan dilakukan secara berkelompok maka bisa menggunakan metode kooperatif dan kolaboratif learning 
c. Pengaturan perilaku dan pemberian motivasi kepada siswa

Dalam proses belajar, sering kali muncul perilaku siswa yang menggangu kondisi kelas. Gangguan dalam kelas harus segera ditangani oleh guru, bisa memberikan hukuman (punishment). Untuk siswa yang berperilaku baik siswa juga perlu diberikan penghargaan (reward). Hal ini dilakukan untuk menumbuhkan motivasi siswa (Hurlock, 2011, 78).

Motivasi sendiri menurut clayton dalam Nashar (2004, 42) merupakan kecendrungan siswa dalam melakukan kegiatan belajar yang didorong oleh hasrat untuk mencapai prestasi atau hasil belajar sebaik mungkin. Motivasi adalah kekuatan yang mendorong siswa untuk belajar dengan senang dan sunggu-sungguh yang kemudian membentuk cara belajarnya yang sistematis, penuh konsentrasi dan dapat menyelasaikan kegiatannya dalam pembelajaran.

Catharina (2006, 186-187) menyebutkan beberapa strategi dalam usaha menumbuhkan motivasi belajar siswa antara lain:

1. Membangkitkan minat belajar

Dalam hal ini guru hendaknya berusaha meyakinkan siswa bahwa pengetahuan yang dipelajari mereka itu sangat bermanfaat bagi mereka. Guru bisa meminta siswa untuk memilih materi apa yang akan dipelajari dan cara-cara mempelajarinya.

2. Membangkitkan rasa ingin tahu

Ciri dari guru yang terampil adalah kemampuannya dalam membangkitkan dan memelihara rasa ingin tahu siswa dalam proses pembelajaran. Untuk membangkitkan hasrat ingi tahu siswa, guru bisa menggunakan metode pembelajaran studi kasus, discovery, inquiry, diskusi, curah pendapat dan sejenisnya.

\section{Penyajian Materi yang menarik}

Variasi metode dan penggunaan materi pembelajaran yang menarik juga mampu menarik perhatian peserta didik. Guru dapat menggunakan media pembelajaran seperti menyajikan materi dengan slide, video untuk menarik perhatian siswa. 
4. Membantu siswa dalam merumuskan tujuan belajar

Prinsip yang mendasar dari motivasi adalah anak akan belajar keras untuk mencapai tujuan apabila tujuan itu dirumuskan atau ditetapkan oleh dirinya sendiri bukan dirumuskan atau ditetapkan oleh orang lain.

\section{Motivasi Belajar}

Pengertian

Motivasi diartikan sebagai perubahan energi dalam diri seseorang yang ditandai dengan munculnya feeling dan didahului dengan tanggapan terhadap adanya tujuan. Hal yang mendorong sesorang untuk melakukan sesuatu disebut motif. Motif berasal dari dalam diri manusia untuk melakukan aktivitas tertentu untuk mencapai suatu tujuan. Dikatakan motivasi ketika motif/dorongan penggerak itu telah aktif. Motif menjadi aktif apabila kebutuhan untuk mencapai tujuan sudah sangat mendesak (A.M, 1994, 73).

Dalam kegiatan belajar-mengajar motivasi dapat didefinisikan sebagai keseluruhan daya penggerak di dalam diri siswa yang menimbulkan kegiatan belajar, yang menjamin kelangsungan kegiatan belajar dan yang memberikan arah pada kegiatan belajar sehingga tujuan belajar yang dikehendaki dapat tercapai. Motivasi belajar sebagai faktor psikis memiliki peranan sebagai sebab timbulnya semangat belajar siswa, rasa senang siswa terhadap guru dan materi pelajaran, dan terutama meningkatkan minat belajar siswa. Sebab minat berkaitan erat dengan kebutuhan siswa, yang hal tersebut hanya muncul bila siswa melihat pengalaman belajar yang ia dapat memiliki hubungan dengan kepentingannya. Oleh karena itu guru harus mampu menciptakan kondisi tertentu agar siswa selalu butuh dan ingin terus belajar (A.M, 1994, 75-76).

Jenis Motivasi Belajar

Dalam proses belajar mengajar motivasi dapat dibagi menjadi dua (Syaifurahman \& Tri Ujiati, 2013, 170):

1. Motivasi Instrinsik, yaitu dorongan untuk melakukan sesuatu yang berasal dari dalam diri setiap siswa. Siswa yang termotivasi secara instrinsik akan belajar karena benar-benar ingin mendapat pengetahuan, nilai atau keterampilan agar dapat berubah tingkah lakunya. Siswa belajar bukan karena tujuan yang lain 
seperti ingin mendapat pujian, karena ujian dan lainnya. Siswa yang memiliki ciriciri motivasi instrinsik dapat dilihat indikator berikut (A.M, 1994, 83):
a. Tekun dalam mengerjakan tugas
b. Ulet menghadapi kesulitan
c. Menunjukkan minat terhadap bermacam-macam masalah.
d. Lebih senang bekerja mandiri
e. Cepat bosan pada tugas-tugas yang rutin
f. Dapat mempertahankan pendapatnya (kalau sudah yakin akan sesuatu)
g. Tidak mudah melepaskan hal yang diyakini.
h. Senang mencari dan memecahkan masalah soal-soal.

2. Motivasi Ekstrinsik, yaitu dorongan untuk melakukan sesuatu yang berasal dari luar diri siswa. Motif siswa untuk belajar disebabkan adanya stimulus dari guru, orang tua, teman. Jadi siswa belajar bukan karena keinginannya sendiri, tapi tujuan lain seperti ingin mendapatkan hadiah, pujian dari guru, teman, atau belajar hanya karena akan ujian. Jadi faktor-faktor luar tersebut secara mutlak tidak berkaitan dengan aktivitas belajar.

Motivasi ekstrinsik diperlukan karena beberapa hal meliputi, sifat kondisi siswa yang dinamis, materi pelajaran yang sulit, metode guru yang kurang menarik bagi siswa. Guru dapat menumbahkan motivasi diri siswa dengan memberikan stimulus berupa penilaian angka, hadiah, pujian, hukuman, menciptakan persaingan atau kompetisi, ego-involvement, memberi ulangan, memberi tahu hasil belajar pada siswa.

\section{Strategi Pengelolaan Motivasi}

Indikator dari motivasi belajar siswa dapat dilihat dari usaha yang ia lakukan selama mengikuti kegiatan belajar di kelas. Secara operasional motivasi belajar ditentukan oleh indikator-indikator berikut (Wena, 2010, 34-49):

a. Perhatian (attention)

Strategi dalam membangkitkan dan mempertahankan perhatian siswa dalam pembelajaran guru dapat melakukan tiga hal berikut:

1. Membangkitkan daya persepsi siswa 
Hal ini dapat merangsang rasa ingin tahu siswa. Gguru melakukan hal itu dengan menggunakan sesuatu hal yang baru, mencengangkan, membingungkan, atau sesuatu yang kontradiktif. Penggunaan efek audio visual seperti animasi; menggunakan peristiwa atau konteks yang tidak biasa atau aneh (tetap pada batas wajar) dapat memunculkan konflik pada diri siswa kemudian muncul motivassi siswa akan berusaha untuk menghilangkan konflik tersebut.

2. Merangsang timbulnya rasa ingin tahu

Secara operasional di dalam kelas guru dapat merangsang hasrat ingin mencari informasi/meneliti siswa dengan cara berikut:

Aktif merespons, menggunakan interaksi pertanyaan-respons-umpan balik.

Menciptakan masalah, memberi kesempatan siswa untuk memecahkan masalah Menciptakan misteri, yaitu menciptakan situasi pemecahan masalah dalam konteks yang membutuhkan eksplorasi.

3. Menggunakan elemen pembelajaran secara variatif

Meringkas bagian pembelajaran, membuat

Menyajikan informasi yang beraneka ragam secara interaktif

Mengintegrasikan media yang fungsional

b. Relevansi (relevance)

Mengaitkan pembelajaran dengan kebutuhan siswa dapat dilakukan dengan strategi berikut:

Menumbuhkan Keakraban dan kebiasaan yang baik secara operasional meliputi:

1. Penggunaan bahasa atau ungkapan-ungkapan yang dikenal siswa

2. Penggunaan ilustrasi yang sesuai

3. Penggunaan ilustrasi gambar untuk menjelaskan konsep yang abstrak/tidak biasa bagi siswa

4. Penggunaan contoh dalam menjelaskan hendaknya dikaitkan dengan pengalaman dan nilai kehidupan siswa.

Berorientasi pada tujuan

1. Menginformasikan apa yang harus dicapai siswa pada akhir pembelajaran

2. Memberikan penjelasan tugas-tugas dan manfaat dari mengerjakan tugas tersebut. 
Penggunaan strategi mengajar yang sesuai dengan profil/karakter siswa dapat dilakukan dengan cara:

1. Memberi kesempatan pada siswa memilih tujuan-tujuan yang beraneka rangam

2. Menggunakan sistem skorsing dan umpan balik terhadap unjuk kerja siswa

3. Menyajikan pilihan-pilihan yang memungkinkan siswa bekerja bersama teman lainnya.

\section{Metodologi Penelitian}

Metode penelitian diartikan sebagai cara ilmiah untuk mendapatkan data dengan tujuan dan kegunaan tertentu (Sugiyono, 2013, 3). Penelitian harus mengikuti prosedur yang sudah baku baik dari pemilihan jenis penelitian, subjek penelitian, data dan sumber data, teknik pengumpulan data yang akan digunakan, instrument yang digunakan, serta cara menguji keabsahan data (validasi). Oleh karena penting bagi peneliti untuk menjelaskan masing-masing bagian metodologi penelitian tersebut:

a. Jenis Penelitian

Jenis pendekatan penelitian yang digunakan adalah kualitatif. Pendekatan kualitatif digunakan untuk mengungkapkan data deskriptif dari informasi tentang apa yang subjek penelitian lakukan, dan yang mereka alami terhadap fokus penelitian. Prosedur pemecahan masalah yang diselidiki dengan menggambarkan/melukiskan keadaan subjek/objek penelitian pada saat sekarang berdasarkan fakta-fakta yang tampak atau sebagaimana adanya yang disebut sebagai metode deskriptif (Nawawi, 2012, 67) sangat sesuai dengan masalah yang akan diteliti. Dengan demikian bentuk penelitian ini adalah kualitatif dengan metode deskriptif. Hadari Nawawi $(2012,38)$ menyatakan bahwan Metode deskriptif adalah suatu metode dalam meneliti status kelompok manusia, suatu objek, suatu set kondisi, suatu sistem pemikiran dan suatu kelas peristiwa pada masa sekarang. Pada penelitian ini, para peneliti berusaha menggambarkan kegiatan penelitian yang dilakukan pada objek tertentu dengan jelas dan sistematis.

b. Sumber Data

Sumber data primer penelitian ini adalah hasil observasi, wawancara, dan catatan singkat dari dosen dan mahasiswa di kelas PKPBA UIN Maulana Malik Ibrahim. Adapun data sekunder penelitian ini dari dokumen-dokumen yang berkaitan dengan 
proses pembelajaran bahasa arab seperti, rencana pembelajaran, dan nilai hasil belajar siswa.

c. Teknik Pengumpulan Data

Penelitian ini menggunakan observasi, dan wawancara, serta dokumentasi. Dalam hal ini jenis observasi yang digunakan adalah observasi partisipasi pasif yang dimana peneliti hadir di tempat penelitian namun tidak terlibat dalam kegiatan objek yang diamati (Sugiyono, 2018, 310-311). Alasan pemilihan observasi partisipasi pasif untuk melihat aktivitas guru dalam melakukan pengelolaan kelas dan kegiatan siswa saat proses belajar mengajar.

Kemudian wawancara yang digunakan jenisnya adalah wawancara baku terbuka. Wawancara ini menggunakan seperangkat pertanyaan baku yang telah disusun oleh peneliti didasarkan atas masalah dalam rancangan penelitian. Dikatakan terbuka adalah subjek mengetahui bahwa mereka sedang diwawancarai, mengetahui apa maksud dan tujuan wawancara itu. Dalam hal ini petunjuk wawancara disusun sebelum diadakannya wawancara (Moleong, 2017, 187).

Teknik lainnya yang digunakan dalam penelitian ini adalah metode dokumentasi yang dilakukan untuk mengumpulkan data historis (Bungin, 2010, 121). Data-data historis yang dimaksud berkaitan dengan hal-hal yang berkaitan dengan proses pembelajaran di kelas, meliputi desain pembelajaran, perangkat pembelajaran, proses kegiatan belajar mengajar maupun evaluasi. Data dokumentasi ini dimaksudkan untuk memperkuat temuan dari teknik pengumpulan data lainnya.

\section{d. Teknik Analisis Data}

Dalam penelitian ini menggunakan model Miles dan Huberman dalam analisis data memiliki tiga tahapan: 1) mereduksi data adalah proses merangkum, memilih halhal pokok, menelusur tema dan pola, serta mentransformasi data. 2) menyajikan data dengan bentuk teks narasi dari data yang telah direduksi. Dan juga dapat menggunakan grafik, matrik, tabel dan sejenisnya. 3) Menarik kesimpulan dapat dilakukan ketika datadata yang ditemukan valid dan konsisten saat peneliti mengulangi pengumpulan data ke lapangan (Sugiyono, 2018, 334-343). 


\section{e. Teknik Validasi Data}

Pengecekan keabsahan data pada penelitian ini menggunakan peningkatan ketekunan bermaksud melakukan pengamatan dengan lebih cermat dan berkesinambungan; menggunakan bahan referensi (alat bantu seperti camera, handycam, alat rekam) sebagai pendukung bukti yang ditemukan peneliti, dan terakhir melakukan member checking yakni proses pengecekan data yang diperoleh peneliti kepada pemberi data (responden) (Sugiyono, 2018, 366-372).

\section{Hasil dan Pembahasan}

Keterampilan Pengelolaan Kelas

Dosen sebagai manajer di dalam kelas harus memiliki tiga kemampuan pengelolaan kelas untuk mencapai pembelajaran yang efektif. Tiga kemampuan tersebut meliputi Perencanaan, Pelaksanaan, dan Pengendalian (evaluasi). Dalam kegiatan belajar mengajar dosen yang PKPBA yang menjadi subjek peneliti didapati sudah memenuhi indikator diatas namun kurang maksimal dalam pelaksanaanya. Berikut ketiga keterampilan yang dilakukan oleh dosen PKPBA dalam mengelola kelas:

\section{a. Perencanaan Perkuliahan oleh Dosen}

\section{Merencanakan tujuan dan kompetensi}

Sebelum melaksanakan perkuliahan dosen dituntut untuk menentukan tujuan dan kompetensi yang akan dicapai oleh mahasiswa. Dan juga harus mampu mengambil keputusan yang tepat dalam mengelola sumber daya (siswa) dan sumber belajar untuk membentuk kompetensi dasar dan mencapai tujuan pembelajaran. Dosen pada matakuliah kalam yang merupakan subjek penelitian ini dari data yang diperoleh sudah melakukan perencanaan sebagai berikut: a). Dosen menganalisis kebutuhan belajar mahasiswa, 2). Dosen menentukan kompetensi belajar yang relevan, 3). Menyiapkan lingkungan fisik yang memadai, 3). Mercancang tahapan-tahapan perkuliahan dan peraturan. Empat hal ini adalah hasil pengamatan dan juga wawancara peneliti terhadap dosen. Dari data tersebut ketika kita kaitkan dengan teori yang dipaparkan oleh Mulyasa (2008, 77-78) bahwa guru dalam langkah perencanaan hendaknya mampu mengambil keputusan untuk mengelola sumber daya (siswa) dan sumber belajar untuk menentukan kompetensi dan tujuan pembelajaran. 
Dari tiga kelas yang peneliti amati, dosen memilih dan menetukan variasi mengajar yang berbeda dengan pertimbangan bahwa latar belakang peserta didik itu berbeda antara tiga kelas yang diajar oleh dosen kalam tersebut. Untuk kelas Syariah-1 metode yang dipilih adalah mendemonstrasikan hasil kinerja mahasiswa. Pada kelas Tarbiyah-1 menggunakan kuis sambung kata, prediksi kata, tebak-tebakan dengan berbahasa arab. Sedangkan pada kelas Tarbiyah-3 menggunakan metode ceramah dan tanya jawab.

Disampaikan bahwa pemilihan metode yang beragam tersebut untuk tujuan meningkatkan motivasi belajar siswa. Mengingat sebelumnya para mahasiswa telah melalui pembelajaran dari pagi hari sampai siang hari. Tentu rasa letih dan lelah dapat memengaruhi motivasi internal mereka untuk belajar bahasa arab di kelas pada sore hari. (Wawancara, 22 November, 13.30 WIB).

Dalam hal perencanaan dosen semestinya menyampaikan tujuan-tujuan pembelajaran, dan langkah-langkah pembelajaran yang akan dilaksanakan agar mahasiswa memiliki gambaran awal pembelajaran yang akan mereka ikuti. Karena dengan adanya kaitan antara kompetensi baru (pengetahuan) terhadap pengalaman pribadi mereka atau dengan pengetahuan mereka sebelumnya akan merangsang motif belajar yang ada pada diri mereka.

\section{Pengaturan kondisi fisik kelas}

Pengaturan iklim kelas pada dasarnya bersifat fleksibel, dalam arti bergantung pada guru, kelas, murid, besar ruangan, suhu, dan penerangan. Dari hasil pengamatan di kelas Syariah-1, Tarbiyah-1 dosen mengatur posisi kursi membentuk letter U. Disini dosen berusaha menjadikan mahasiswa sebagai subjek yang belajar. Dosen hanya sebagai fasilitator di dalam kelas. Sedangkan pada kelas Tarbiyah-3 model kursi diatur seperti tata kursi tradisional yang menempatkan satu meja guru berhadapan dengan meja kursi siswa. Kelas yang ditata secara tradisional tersebut menempatkan guru sebagai pusat kegiatan dan sentra perhatian murid. Sehingga murid disini sebagai objek pengajaran. Perbedaan pengaturan pola kursi nyatanya memengaruhi keefektifan kegiatan belajar mengajar di kelas. Untuk kelas Tarbiyah-3 didapati ada beberapa mahasiswa yang bermain handphone, berbicara dengan temannya saat dosen menjelaskan. Saat di wawancara mahasiswa tersebut selain karena metode mengajar 
ceramah dan tanya jawab yang membosankan tapi juga tata pola kursi memengaruhi motif belajar mereka.

\section{b. Pelaksanaan Pembelajaran}

Pelaksanaan manajemen kelas yang efektif dalam pembelajaran ketika dapat mewujudkan kondisi kelas sebagai lingkungan pembelajaran yang memungkinkan siswa untuk mengembangkan kemampuan seoptimal mungkin, menghilangkan berbagai hambatan yang dapat menghalangi interaksi pembelajaran, menyediakan dan mengatur fasilitas yang mendukung siswa belajar sesuai dengan lingkungan sosial, emosional dan intelektual siswa, serta dapat membimbing siswa sesuai dengan latar sosial, ekonomi, budaya dan sifat/karakter siswa yang berbeda. Oleh karena itu, dalam pelaksanaan pembelajaran perlu diketahui kondisi dan masalah yang terjadi pada siswa pada saat pembelajaran berlangsung.

Setiap ada permasalahan yang terkait dengan sikap siswa dan masalah ekstern lainnya, seorang guru berusaha untuk mencari solusinya pada saat itu juga, agar tanggung jawab guru berfungsi dengan maksimal. Dalam mengelola pembelajaran Dosen matakuliah Kalam menggunakan beberapa strategi pembelajaran: 1). Menjelaskan materi dengan bahasa arab yang mudah dan sering dipakai, 2). Menggunakan isyarat atau mempraktekkan kosa kata baru untuk mengetahui maknanya, 3). Menyampaikan materi secara urut, 4). Memberikan jeda waktu kepada mahasiswa untuk menjawab pertanyaan yang dilontarkan, 5). Dosen memberikan penekanan dengan mengeraskan suara pada, 6). Memerhatikan isyarat non-verbal dari mahasiswa yang menandakan mahasiswa bosan, 7), menulis pokok pembelajaran di papan tulis, 8). Memberikan contoh-contoh yang mudah dan dekat dengan pengalaman mahasiswa. Dari tujuh poin yang peneliti dapatkan di kelas Syariah-1, Tarbiyah-1 dan 3 adalah poin indikator 6 dan 7 belum terlaksana oleh dosen. Dosen saat di tiga kelas tersebut seperti mengabaikan isyarat, gerak-gerik mahasiswa yang menandakan kebosanan terhadap kegiatan belajar mengajar yang kemudia membuat gangguan di kelas seperti berpindah-pindah tempat duduk. Dan poin 7 juga dosen tidak menuliskan pokok pembelajaran di papan tulis.

\section{c. Pengendalian Dalam kelas}

Dalam proses belajar mengajar tentu akan didapati gangguna di kelas mengingat kondisi peserta didik bersifat dinamis mudah berubah. Sehingga pengajar perlu 
melakukan pemberian respon yang positif untuk perilaku yang diharapkan dari siswa dan respon negatif seperti hukuman, teguran untuk siswa yang perilaku negatif. Sebagai manajer dalam kelas dosen seharusnya memiliki indikator berikut: 1) Memberikan pujian kepada peserta didik yang aktif menjawab dan bertanya, 2). Memberi teguran yang bijaksana, 3). Memberi penilaian berupa angka untuk tugas yang dikerjakan, 4). Memberikan hukuman fisik yang sewajarnya bila diperlukan, 5). Memberikan penghargaan kepada mahasiswa yang meningkat prestasinya. Dalam pengamatan selama di tiga kelas secara keseluruha dosen matakuliah kalam telah melaksanakan indikator diatas hanya saja untuk pemberian pujian atas jawaban dan pertanyaan mahasiswa jarang sekali dilakukan dosen. Dosen pada kesempatan tertentu mengabaikan sikap mahasiswa yang terkesan kurang sopan dengan alasan karena peserta didik tingkat perkuliahan berbeda pemberian hukumannya dengan tingkat menengah dasar.

\section{Simpulan}

Berdasarkan data hasil penelitian dan pembahasan dalam penelitian ini maka dapat ditarik kesimpulan bahwa manajemen kelas di kelas PKPBA UIN Maulana Malik Ibrahim Malang yang dilakukan oleh dosen mata kuliah kalam dalam menyiapkan kelas, Mengendalikan kelas saat proses belajar mengajar, menyajikan materi, mampu menjadi stimulus (factor ekstrinsik) timbulnya motivasi dalam diri mahasiswa untuk mengikuti pembelajaran, Dalam pemberian penguatan sudah cukup baik, dan dalam pelaksanaan pembelajaran secara umum mampu membangkitkan motivasi belajar mahasiswa. Meskipun terkadang, beberapa usaha yang dilakukan oleh dosen dalam mengelola kelasnya masih mendapati kendala-kendala menciptkan kondisi/iklim belajar yang kondusif dan efektif.

\section{Saran}

Berdasarkan hasil penelitian yang diperoleh serta pembahasan tentang hasil tersebut, maka peneliti memilih saran-saran sebagai berikut: 1). Dalam perencanaan hendaknya menyampaikan pada mahasiswa tujuan-tujuan pembelajaran yang akan dicapai. 2). Menuliskan hal-hal pokok di papan tulis ada ringkasan dalam slide powerpoint. 3). Dosen harus mampu membaca isyarat non-verbal dari mahasiswa yang menunjukkan kebosanan, atau ketidakpahaman terhadap materi. 


\section{Daftar Pustaka}

A.M, S. (1994). Interaksi dan Motivasi Belajar Mengajar. Jakarta: PT RajaGrafindo Persada.

Aini, C. T. (2006). Psikologi Belajar. Semarang: UPT UNNES Press.

Arikunto, S. (1990). Manajemen Pengajaran Secara Manusiawi. Jakarta: PT Rineka Cipta.

Arikunto, S. (1992). Pengelolaan Kelas dan Siswa. Jakarta: Rajawali.

Bungin, M. B. (2010). Penelitian Kualitatif: Komunikasi, Ekonomi, Kebijakan Publik dan Ilmu Sosial Lainnya. Jakarta: Kencana.

Djamarah, S. B. (2006). Strategi Belajar Mengajar. Jakarta: PT Rineka Cipta.

Fathurrohman, Pupuh \& M. Sobry Sutikno. (2011). Strategi Belajar Mengajar melalui Penanaman Konsep Umum dan Konsep Islam. Bandung: PT Refika Aditama.

Hurlock, E. (2011). Psikologi Perkembangan: Suatu Pendekatan Sepanjang Rentang Kehidupan. Jakarta: Erlangga.

Majid, A. (2006). Perencanaan Pembelajaran. Bandung: Remaja Rosdakarya.

Moleong, L. J. (2017). Metodologi Penelitian Kualitatif. Bandung: PT Remaja Rosdakarya.

Mulyasa, E. (2005). Menjadi Guru Profesional Menciptakan Pembelajaran Kreatif dan Menyenangkan. Bandung: Remaja Rosda.

Mulyasa, E. (2008). Standar Kompetensi dan Sertifikasi Guru. Bandung: Remaja Rosda Karya.

Nashar. (2004). Peranan Motivasi dan Kemampuan Awal dalam Kegiatan Pembelajaran. Jakarta: Delia Press.

Nawawi, H. (2012). Metode Penelitian Bidang Sosial. Yogyakarta: Gajah Mada University Press.

Nizar, S. (2002). Filsafat Pendidikan Islam. Jakarta: Ciputat Pers.

Rianto, M. (2007). Pengelolaan Kelas Model PAKEM. Jakarta: Dirjen PMPTK.

Rohani, A. (2010). Pengelolaan Pengajaran. Jakarta: PT Rineka Cipta.

Santrock, J. W. (2008). Psikologi Pendidikan. Jakarta: Prenada Media Group.

Sugiyono. (2013). Metodologi Penelitian Pendidikan (Pendekatan Kuantitatif, Kualitatif, $R$ \& D). Bandung: Alfabeta. 
Sugiyono. (2018). Metode Penelitian Kombinasi. Bandung: Alfabeta.

Ujiati, S. \&. (2013). Manajemen dalam Pembelajaran. Jakarta: PT Indeks.

Wena, M. (2010). Strategi Pembelajaran Inovatif Kontemporer. Jakarta: Bumi Aksara. 